all in the room. We found the tumbler shattered into fragments, the body of the glass ripped up, as it were, into several large, irregular-curved pieces, and the bottom of the tumbler broken into small pieces more resembling thick rough ice than anything else. Query: Was the explosion caused by the inherent properties of the toughened glass, or by the contact of potash, soda, the silver spoon, and proximity to a lamp, the heat from which was very slight, indeed scarcely perceptible to the hand at the spot where the tumbler stood?

The accident might have been very serious, for pieces of the glass flew to within a very few inches of the lady's face. A solution of the cause of the explosion is therefore of considerable importance to all who may have occasion to use vessels of this peculiar glass.

Sunninghill, July 7

\section{Great Meteor}

A METEOR of extraordinary brilliancy was seen on Friday, July 9 , about 8.20 p.m.- -almost in full daylight, the sun having only just set-by the Rev. Mr. Lloyd-Jones, who kindly took me to the place of observation and gave me the following particulars :-

The meteor was quite half as large as the full moon, of dazzling light-blue colour. It moved slowly in a path inclined about 1o to the horizon, from left to right, and emitted a train of ruddy sparks. Mr. Lloyd-Jones was looking in the opposite direction, and had time, after his attention was called to it by a friend, to turn round and see the last $10^{\circ}$ of the path. The total duration may have been ten seconds, and could not have been less than five, the meteor dying out slowly. The point of dicappearance was carefinlly noted and referred to some trees about 200 yards distant. I afterwards found it to be in true azimuth N. $691^{\circ} \mathrm{E}$., altitude $9^{\circ}$. No detonation was heard. The place of observation was about two-thirds of a mile east of the Royal Observatory, Greenwich.

G. L. TUPMAN

\section{Iron and Hydrogen}

MAY I be allowed to point out that the question of the occlusion of bydrogen in steel, and its influence in hardening, has been discussed by $\mathrm{Mr}$. Wm. Anderson in his report to the Committee of this Institution on the Hardening, \&c., of steel

At the last meeting of this Institution Prof. Hughes stated that his experiments did not support the hydrogen theory, but rather the view that hardened steel was an actual alloy of carbon and iron, unhardened steel a mixture only. I may add that experiments are now in progress, designed to test the truth of this latter view.

Institution of Mechanical Engineers, July i2

WALTER R. BROWNE Secretary

\section{The Stone in the Nest of the Swallow}

The swallow stone is the agate pebble, called in French cheledoine - the name given to the chalcedony (NATURE, vol, $x x i$. p. 494), but the same virtue is attributed to the swallow herb. This is the Chelidonium majus, about which Britten and Holland, in their "English Plant Names," give the following quotation from Lyte:- "Chelidonium, that is to say, swallowherbe, bycau e (as Plinie writeth) it was first found out by swallowes and hath healed the eyes and restored sight to their young ones that had harme in their eyes or have bene blinde."

Littré, in his great Dictionnaire, gives two quotations, in which Chetedoine is used in a botanical sense :-

$$
\begin{aligned}
& \text { "Se vus avez as oils manjue } \\
& \text { Dunc prenez celedoine et rue." }
\end{aligned}
$$

MS. St. Fean, I $3^{\text {th }}$ century.

"Aussi les guerit le jus de cheledoine, le lait de tithymal."Pare, v. 21, 16!h century.

He also gives its meaning as the name of a precious stone, and adds: "Petits cailloux appartenant aux agates, on dit aussi pierres d'hirondelle." With respect to its etymology he says he derives it from " $\chi € \lambda เ \delta \delta \nu t o \nu$, de $\chi € \lambda เ \delta \omega \nu$, hirondelle, à cause qu'on disait que l'hirondelle se servait de cette plante pour rendre la vue à ces petits."

Fern Bank, Higher Broughton, Manchester

\section{THE CARIBBEAN SEA}

THE Coast Survey steamer Blake, Commander J. R. Bartlett, U.S.N., Assistant Coast Survey, recently returned from a cruise taking soundings, serial temperatures, \&c., in the course of the Gulf Stream, under instructions from C. P. Patterson, Superintendent Coast and Geodetic Survey, has brought very interesting data in regard to the depths of the western portion of the Caribbean Sea.

The depths and temperatures obtained last year in the "Windward Passage" between Cuba and San Domingo were verified, and a few hauls of the dredge taken directly on the ridge in this passage. The data obtained render it very probable that a large portion of the supply for the Gulf Stream passes through this passage, and that the current extends in it to the depth of 800 fathoms. A few lines of soundings with serial temperatures were run from Jamaica to Honduras Bank, viá Pedro and Rosalind Banks, and it was found that the temperature of $39 \frac{1}{2}^{\circ}$, obtained at all depths below 700 fathoms in the Gulf of Mexico and the Western Caribbean, could not enter through this portion of the sea. But the temperature at the depth of 800 fathoms on the ridge in the "Windward Passage" between Cuba and Hayti was found to agree with the normal temperature of the Caribbean and Gulf of Mexico, viz., 391 $\frac{1}{2}^{\circ}$. Soundings were taken between Hayti and Jamaica, developing a general depth between these islands not exceeding 800 fathoms, except where broken by a remarkably deep channel connecting the waters of the main Caribbean south of San Domingo with those north of Jamaica. This channel runs close to Hayti with a greatest depth of 1,200 fathoms, and a general depth of 1,000 fathoms. Its course is northerly along the western end of Hayti, where it does not exceed a width of 5 or 6 miles; thence westerly, south of Navassa Island, with a tongue to the northward between Navassa and Foxmigas Bank, and another to the westward between Foxmigas Bank and Jamaica.

A line of soundings was run from San Iago de Cuba to the east end of Jamaica, where a depth of 3,000 fathoms was found 25 miles south of Cuba. This deep place was found by subsequent soundings to be the eastern cnd of an immense deep valley extending from between Cuba and Jamaica, to the westward, south of the Cayman Islands, well up into the Bay of Honduras. The Cayman and the Misteriosa Bank were found to be summits of mountains belonging to a submarine extension (exceedingly steep on its southern slope) of the range running along the south-eastern side of Cuba. This deep valley is quite narrow at its eastern end, but widens between the western end of Jamaica and Cape Cruz, where the soundings were 3,000 fathoms within 15 miles of Cuba, and 2,800 fathoms within 25 miles of Jamaica. Near Grand Cayman the valley narrows again, but within 20 miles of this island a depth was found of 3,428 fathoms. The deep water was carried as far as a line between Misteriosa Bank and Swan Isiands, with 3,0ro fathoms within 15 miles of the latter. On a line between Misteriosa Bank and Bonacca Island there was a general depth of 2,700 fathoms, and a depth of over 2,000 fathoms extended well into the Gulf of Honduras. Between Misteriosa Bank and Chinchorro Bank the soundings were regular at 2,500 fathoms. North of Misteriosa and Grand Cayman, to the Isle of Pines and Cape San Antonio, the soundings were generally 2,500 fathoms. The serial temperatures agree, in relation to depth, with those obtained in the Gulf of Mexico, by Lieut. Commander Sigsbee, and in the Eastern Caribbean by Commander Bartlett; decreasing from the surface to $392^{\circ}$ at 700 fathoms, or less, and constant at that temperature for all depths below 700 fathoms. At greater depths than 600 or 700 fathoms the bottom was always found to be calcareous ooze composed of Pteropod shells with small 
particles of coral. These Pteropod shells, as noted in previous expeditions by different nations, appear to be an important factor in the determination of the movements of great bodies of sea-water. The ridge at the "Windward Passage" is bare coral rock, and on the south side the Pteropod shells were found to be much more numerous than to the northward of the ridge. Soundings and serial temperatures being the special objects of the course, dredgings were only incidentally attempted for the purpose of reconnoitring, as it were, the ground, and it was found that the area passed over was not nearly so rich in animal life as that in which dredgings were taken last year under the lee of the Windward Islands at the eastward of the Caribbean Sea.

The development of the extraordinary submarine valley in the western Caribbean Sea is a matter of great interest considered as a physical feature. This valley extends in length 700 statute miles from between Jamaica and Cuba nearly to the head of the Bay of Honduras, with an average breadth of 80 miles. Curving around between Misteriosa Bank and Yucatan, and running along between Cuba and the ridge of the Caymans for a distance of 430 miles, with a breadth of 105 miles, it covers an area of over 85,000 square miles, having a depth nowhere less than 2,000 fathoms, except at two or three points (the summits of submarine mountains), with a greatest depth, 20 miles south of the Grand Cayman, of 3,428 fathoms, thus making the low island of Grand Cayman, scarcely 20 feet above the sea, the summit of a mountain 20,568 feet above the bottom of the submarine valley beside it - an altitude exceeding that of any mountain on the North American continent, above the level of the sea, and giving an altitude to the highest summit of Blue Mountain in Jamaica, above the bottom of the same valley, of nearly 29,000 feet, an altitude as great, probably, as that of the loftiest summit of the Himalayas above the level of the sea.

For the deepest portion of this great submarine valley the Superintendent of the Cuast and Geodetic Survey has adopted the name of "Bartlett Deep."

\section{ALBANIA AND THE ALBANIANS}

$\triangle B O U T$ the dawn of authentic history the Balkan peninsula seems to have been mainly occupied by two kindred Aryan peoples--the Hellenes in the south, the Thrako-Illyrians in the north. Since then, or, say, for some 3,000 years, this region has been swept by more numerous tides of migration than almost any other country on the globe. Some of these waves, such as those of the Kelts 300 years before, and of the Goths 400 years after, the Christian era, receded without leaving any permanent traces behind them. Some, such as the Romans, are still represented by the Dako-Rumanians of the Danubian principalities and their southern kinsmen, the Zinzars or Kutzo-Vlachs of the Pindus range and Thessaly. Others, such as the Ugrian Bulgars, have been absorbed or assimilated to the Slaves, intruders like themselves, while others again have either resettled the land, as, for instance, the Serbo-Croatians, or else, like the Osmanli of Tûrki stock, have seized the political control without making any serious attempts at colonisation. The result is a condition of things absolutely without a parallel elsewhere-an utter chaos of races, languages, religions, a clash of social interests and national aspirations, which has long threatened the peace of the world, and the means of reconciling which the wisest heads have hitherto failed to discover.

But beneath and above all these strange vicissitudes and endless complications the two relatively aboriginal elements of the population still here and there hold their ground. The Hellenes have doubtless been largely Slavonised almost everywhere on the mainland, ${ }^{1}$ although

" "La Grèce devint une Slavie, et l'idiome géréral fut une langue Slave" (E. Reclus, i. p. 62). even here the old Dorians are still believed to survive in the Zakonians of the Spartan hills and the Mainotes of the Tænarum peninsula. The northern branch, also, of what has not inaptly been called the Thrako-Hellenic family still predominates, and even retains a certain vitality, in the Albanian highlands. Thracians, Pæonians, Dardanians, Mœsians, and all the other eastern and northern members of the race have long been extinct as independent nationalities; but the Illyrian or western branch still continues to be represented by the Shkipetars in their original home, on the south-eastern shores of the Adriatic.

The term Albania, it is needless to say, possesses no administrative significance, nor even any very strictlydefined geographical limitations. It is purely an ethnographic expression, though even in this sense no longer quite conterminous with the people from whom it is derived. In its widest extent Albania stretches from the Montenegrin and Servian frontiers southwards to Greece, and from the Pindus, Grammos, and Char Dagh ranges westwards to the coast. Within this area are comprised three nearly coincident physical and ethnical divisions, for everything here seems to run in triads, so that the more technical data necessary to understand a somewhat intricate subject may be conveniently summed up in the subjoined series of triplets :-

I. THREE NATURAL Divisions.-r. Upper Albania, reaching as far south as the river Shkumbi, about $41^{\circ} \mathrm{N}$. lat., and mainly comprised in the Drin basin. 2. Central Albania, between the Shkumbi and Voyussa rivers, mainly in the Ergent basin. 3. Lower Albania, or Epirus, ${ }^{1}$ thence to the present Greek frontier (Akarnania).

II. THREe POLITICAL Divisions. - The Turkish vilayets of Isgodra (Skutari), Monastir or Qosowa, and Yanina, the two former stretching eastwards beyond the actual limits of Albania proper, most of the third awarded to Greece by the Berlin Conference, which has just concluded its labours in connection with the settlement of the new Turko-Greek frontier.

III. THREE GREAT LAKES.-Those of Skutari, Okhrida, and Yanina, convenient landmarks, a curve described through which from about Antivari to Prevesa, both on the coast, will roughly mark the inland frontier line of Albania proper.

IV. THREe Main Racial Elements.-I. The old Thrako-Illyrian, now everywhere largely intermingled with 2, The Slav (Serbo-Croatian branch) in the north, and with 3, The Hellenic (Dorian branch) in the south.

V. THREE COLLECTIVE ETHNICAL OR NATIONAL NAMES.-1. Shkipetar, the most general national appellative of the people, whence Shkiperia (in the Northern dialect Sipenia) the country, and Shkipeia, the language; from root Shkip, Shkup = rock; compare Greek, $\sigma \kappa o ́ \pi \epsilon \lambda o s$; Latin, scopulus; and Ptolemy's old Dardanian town of Skupi. Hence Shkipetar = hillmen, highlanders, according to the most accepted interpretation. 2. Albanian, unknown, at least in this form, to the natives, yet of respectable antiquity, and now mainly current in the west of Europe and Greece. The word is usually referred to the Keltic or Aryan root $a l b$, alp = height, snowy crest, and has been connected with Ptolemy's Albani, a small tribe whose chief town was Albanopolis, north-west of the Lychnitis Palus (Lake Okhrida). As a general name it occurs first in the Byzantine writings of the eleventh

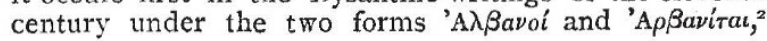

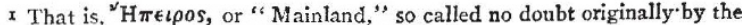
Greeks of the adjacent island of Korkyra (Corfu)

2 Kedrenus, Skylitzes, Anna Comnena. In Georg. Akropol. ("Annals," c. 68) occurs the expression $\tau \delta \tau \hat{\omega} \nu$ 'A $\rho \beta \alpha \nu \imath \tau \hat{\omega} \nu$ है $\theta \nu 0 s$. The forms Arberi or Arbernia for the land, and Arbereshi for the people are even still current amongst the Northern Albanians, and must at one time have been very general, for the various Albanian colonies settled in South Italy since the latter half of the fifteenth century even now call themselves Arbrèsh or Arberesh, and their language Arbrishte or Arberishte. In Greece also

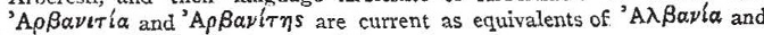
'A $\lambda \beta \alpha \nu \delta$ s. 